\title{
Transcriptomic analysis of Pak Choi under acute ozone exposure revealed regulatory mechanism against ozone stress
}

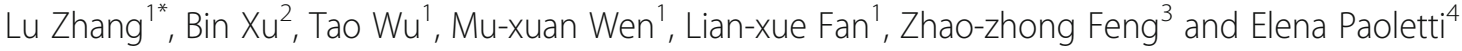

\begin{abstract}
Background: Ground-level ozone $\left(\mathrm{O}_{3}\right)$ is one of the major air pollutants, which cause oxidative injury to plants. The physiological and biochemical mechanisms underlying the responses of plants to $\mathrm{O}_{3}$ stress have been well investigated. However, there are limited reports about the molecular basis of plant responses to $\mathrm{O}_{3}$. In this study, a comparative transcriptomic analysis of Pak Choi (Brassica campestris ssp. chinensis) exposed to different $\mathrm{O}_{3}$ concentrations was conducted for the first time.

Results: Seedlings of Pak Choi with five leaves were exposed to non-filtered air (NF, $31 \mathrm{ppb}$ ) or elevated $\mathrm{O}_{3}$ $\left(\mathrm{E}^{-} \mathrm{O}_{3}, 252 \mathrm{ppb}\right)$ for 2 days (8 h per day, from 9:00-17:00). Compared with plants in the NF, a total of 675 differentially expressed genes (DEGs) were identified in plants under $\mathrm{E}-\mathrm{O}_{3}$, including 219 DEGs with decreased expressions and 456 DEGs with increased expressions. Kyoto Encyclopedia of Genes and Genomes (KEGG) analyses revealed that $\mathrm{O}_{3}$ stress invoked multiple cellular defense pathways to mitigate the impaired cellular integrity and metabolism, including 'glutathione metabolism', 'phenylpropanoid biosynthesis', 'sulfur metabolism', 'glucosinolate biosynthesis', 'cutin, suberine and wax biosynthesis' and others. Transcription factors potentially involved in this cellular regulation were also found, such as AP2-ERF, WRKY, JAZ, MYB etc. Based on the RNA-Seq data and previous studies, a working model was proposed integrating $\mathrm{O}_{3}$ caused reactive oxygen burst, oxidation-reduction regulation, jasmonic acid and downstream functional genes for the regulation of cellular homeostasis after acute $\mathrm{O}_{3}$ stress.
\end{abstract}

Conclusion: The present results provide a valuable insight into the molecular responses of Pak Choi to acute $\mathrm{O}_{3}$ stress and the specific DEGs revealed in this study could be used for further functional identification of key allelic genes determining the $\mathrm{O}_{3}$ sensitivity of Pak Choi.

Keywords: Glutathione metabolism, Ozone, Pak Choi, RNA-Seq, Transcriptome

\section{Background}

Tropospheric ozone $\left(\mathrm{O}_{3}\right)$ is generated by reactions between reactive nitrogen oxides $\left(\mathrm{NO}_{\mathrm{x}}\right)$ and volatile organic compounds (VOCs) in the presence of sunlight, and is one of the key atmospheric pollutants due to anthropogenic activities [1]. Ozone impairs the health of human beings, and also causes serious threats to crops, forests and other ecosystems $[2,3]$.

At the cellular level, we know now a great deal about the mechanisms by which $\mathrm{O}_{3}$ causes oxidative damages

\footnotetext{
* Correspondence: caszhanglu@hotmail.com

${ }^{1}$ College of Horticulture and Landscape Architecture, Northeast Agricultural

University, Harbin, China

Full list of author information is available at the end of the article
}

to plants $[4,5]$. Ozone enters the leaves through the stomata and dissolves in apoplastic solutes, where it then subsequently triggers the production of reactive oxygen species [ROS, such as superoxide anion radical $\left(\mathrm{O}_{2}^{-}\right)$and hydrogen peroxide $\left.\left(\mathrm{H}_{2} \mathrm{O}_{2}\right)\right]$ in the plant cell wall in a highly regulated manner, and ultimately leads to activation of defense and other metabolic signaling pathways among which ROS scavenging is the most remarkable cellular response to high $\mathrm{O}_{3}$ concentration [6-8].

Analyses on transcriptomic profiling in response to $\mathrm{O}_{3}$ stress have been reported in a number of model plants, crops and trees, such as Arabidopsis [9-11], Medicago truncatula [12], pepper [13], soybean [14], and aspen 
tree [15], by means of microarray or next-generation sequencing technologies. Many kinds of leafy vegetables are sensitive to $\mathrm{O}_{3}$ pollution [16]. However, knowledge about transcriptomic response to $\mathrm{O}_{3}$ stress in leafy vegetables is very limited [17].

Pak Choi (Brassica campestris L. ssp. chinensis L. Makino) is one of the most consumed vegetables in East Asia with high healthy and commercial values [18]. In our previous study, we found that Pak Choi is sensitive to acute $\mathrm{O}_{3}$ fumigation as reflected by decreased chlorophyll content, increased anthocyanin content, damaged cell membrane integrity, enhanced antioxidative enzyme activities, depressed photosynthetic rate and stomatal conductance, inhibited maximal quantum yield and effective quantum yield of PSII photochemistry [19]. However, the underlying molecular mechanisms for such physiological alterations are not clear. To our best knowledge, there is no previous report on transcriptomic changes of Pak Choi upon $\mathrm{O}_{3}$ exposure. The goal of this study was to identify and characterize key genes encoding the protein and metabolic pathways involved in $\mathrm{O}_{3}$ responses in Pak Choi by using RNA-Seq as the methodological approach with Brassica rapa subsp. pekinensis (Lour.) Hanelt as the reference genome.

\section{Results}

RNA-sequencing of Pak Choi and DEGs between different $\mathrm{O}_{3}$ treatments

The second fully expanded leaves from the top of Pak Choi plants under NF and $\mathrm{E}_{-} \mathrm{O}_{3}$ were used for RNA-Seq. The sequencing results were deposited in the NCBI SRA database (Accession number: SRP100739). In total, $172,380,454$ and $164,874,922$ raw reads were generated from the three replicated NF libraries and the three replicated $\mathrm{E}-\mathrm{O}_{3}$ libraries, respectively (Additional file 1 : Table S1). To ensure the quality of the libraries, adaptor reads, ambiguous reads and low-quality reads were removed (Additional file 2: Figure S1). Finally, a total of $165,289,336$ and $158,294,170$ clean reads were obtained for $\mathrm{NF}$ and $\mathrm{E}-\mathrm{O}_{3}$, respectively (Additional file 1: Table S1), among which $67.63 \%$ reads in NF and $69.89 \%$ reads in $\mathrm{E}-\mathrm{O}_{3}$ were mapped in the Brassica database (BRAD) (Additional file 1: Table S1). The principle component analysis (PCA) of the RNA-seq data showed that reads of the three NF libraries clustered together while those of $\mathrm{E}_{-} \mathrm{O}_{3}$ clustered together (Additional file 3: Figure S2), further supporting the validity of the experimental design and RNA-seq data. Comparing Pak Choi plants under $\mathrm{E}^{-\mathrm{O}_{3}}$ exposure with those in the NF, a total of 675 DEGs were identified, including 219 DEGs with decreased expressions and 456 DEGs with increased expressions (Additional file 4).

\section{Verification of RNA-Seq data by qRT-PCR}

Transcriptional levels of 12 selected DEGs were examined by qRT-PCR in order to validate the reliability of the RNA-Seq data. Among the selected DEGs, three encoded proteins with oxidoreductase activities, two involved in glutathione metabolism, one involved in cell wall formation, and the rest encoded stress-related transcription factors (Table 1). The result showed that qRTPCR data were in similar trend to those of the RNA-Seq, proving the reliability of RNA-Seq results (Table 1).

\section{Functional classification of DEGs}

GO enrichment analysis were conducted in order to classify the possible functions of DEGs. From the DEGs with increased expressions in plants under E$\mathrm{O}_{3}$ exposure, the top enriched terms were 'response to stimulus', 'oxidation-reduction process', 'response to stress', 'multi-organism process', 'regulation of biological quality', 'pathogenesis', and 'defense response' in the category of biological process; in the molecular function category, the 'oxidoreductase activity', 'sequence specific DNA binding transcription factor activity', 'nucleic acid binding transcription factor activity', 'hydrolase activity, acting on glycosyl bonds' and 'hydrolase activity, hydrolyzing O-glycosyl compounds' were the mostly highly enriched; 'extracellular region' and 'apoplast' were highly enriched in the category of cellular component (Fig. 1). For the DEGs with decreased expressions in plants upon $\mathrm{E}_{-} \mathrm{O}_{3}$ treatment, 'organic substance metabolic process', 'primary metabolic process', 'phosphorus metabolic process', 'phosphate-containing compound metabolic process' and 'cellular protein metabolic process' were the highly enriched ones in the category of biological process; and in the category of molecular function, the top enriched terms were 'catalytic activity' and 'anion binding' (Fig. 2).

KEGG pathway enrichment analysis was performed to reveal the enriched pathways. As shown in Fig. 3, enriched pathways of DEGs with increased expressions in plants under $\mathrm{E}-\mathrm{O}_{3}$ were 'glutathione metabolism' [KEGGmap:ath00480], 'phenylpropanoid biosynthesis' [KEGGmap:ath00940], 'sulfur metabolism' [KEGGmap:ath00920], 'glucosinolate biosynthesis' [KEGGmap:ath00966], 'cutin, suberine and wax biosynthesis' [KEGGmap:ath00073],'pentose and glucoronate interconversions' [KEGGmap:ath00040] and 'taurine and hypotaurine metabolism' [KEGGmap:ath00430]. Eleven DEGs between different $\mathrm{O}_{3}$ treatments were involved in 'glutathione metabolism' (Table 2), ten were in 'phenylpropanoid biosynthesis', and five were in 'sulfur metabolism' (Figs. 4, 5, and 6). The enriched pathway of DEGs with decreased expressions in plants under $\mathrm{E}-\mathrm{O}_{3}$ were 'carbon fixation in photosynthetic organisms' [KEGGmap:ath00710], 
Table 1 The expression patterns of selected genes in plants under non-filtered air (NF) or elevated $\mathrm{O}_{3}\left(\mathrm{E}-\mathrm{O}_{3}\right)$ using real-time quantitative RT-PCR and RNA-Seq

\begin{tabular}{|c|c|c|c|c|c|}
\hline \multirow[t]{2}{*}{ Gene } & \multicolumn{2}{|c|}{$\begin{array}{l}\text { Relative expression of the } \\
\text { target gene by qRT-PCR }\end{array}$} & \multicolumn{2}{|c|}{$\begin{array}{l}\text { FPKM value } \\
\text { from RNA-Seq }\end{array}$} & \multirow[t]{2}{*}{ Gene annotation } \\
\hline & NF & $\mathrm{E}-\mathrm{O}_{3}$ & NF & $\mathrm{E}-\mathrm{O}_{3}$ & \\
\hline Bra003517 & $1.07 \pm 0.08 b$ & $2.20 \pm 0.26 \mathrm{a}$ & 0 & 7.74 & glutaredoxin family protein \\
\hline Bra013923 & $1.12 \pm 0.32 b$ & $85.57 \pm 9.21 \mathrm{a}$ & 0 & 5.05 & $\begin{array}{l}\text { XTR9 (XYLOGLUCAN ENDOTRANSGLYCOSYLASE 9); } \\
\text { hydrolase, acting on glycosyl bonds/ } \\
\text { hydrolase, hydrolyzing O-glycosyl compounds/ } \\
\text { xyloglucan:xyloglucosyl transferase }\end{array}$ \\
\hline Bra020878 & $1.54 \pm 0.58 b$ & $93.07 \pm 10.02 \mathrm{a}$ & 0 & 5.90 & basic helix-loop-helix (bHLH) family protein \\
\hline Bra028899 & $1.08 \pm 0.07 b$ & $16.48 \pm 4.00 \mathrm{a}$ & 0 & 12.79 & transcription factor \\
\hline Bra031485 & $0.98 \pm 0.12 b$ & $26.54 \pm 2.01 \mathrm{a}$ & 20.40 & 1091.02 & oxidoreductase \\
\hline Bra038089 & $0.70 \pm 0.26 b$ & $743.15 \pm 58.96 a$ & 3.07 & 329.91 & lipid binding/ structural constituent of cell wall \\
\hline Bra034061 & $0.94 \pm 0.13 b$ & $32.32 \pm 5.79 a$ & 58.71 & 1332.50 & $\begin{array}{l}\text { ATGSTU8 (GLUTATHIONE S-TRANSFERASE TAU 8); } \\
\text { glutathione transferase }\end{array}$ \\
\hline Bra035732 & $2.23 \pm 1.16 b$ & $9.17 \pm 2.00 \mathrm{a}$ & 5.95 & 85.43 & AP2 domain-containing transcription factor, putative \\
\hline Bra010802 & $1.16 \pm 0.15 b$ & $4.74 \pm 0.94 \mathrm{a}$ & 2.48 & 26.20 & $\begin{array}{l}\text { ATGA2OX2 (GIBBERELLIN 2-OXIDASE); gibberellin 2-beta- } \\
\text { dioxygenase }\end{array}$ \\
\hline Bra012938 & $1.47 \pm 0.58 b$ & $6.45 \pm 0.66 \mathrm{a}$ & 30.81 & 318.51 & $\begin{array}{l}\text { ERF104; ethylene-responsive element-binding family } \\
\text { protein }\end{array}$ \\
\hline Bra009445 & $0.78 \pm 0.33 b$ & $100.98 \pm 38.70 a$ & 0 & 69.96 & $\begin{array}{l}\text { KCS19 (3-KETOACYL-COA SYNTHASE 19); acyltransferase/ } \\
\text { catalytic/ transferase, } \\
\text { transferring acyl groups other than amino-acyl groups }\end{array}$ \\
\hline Bra025833 & $0.95 \pm 0.07 \mathrm{a}$ & $0.30 \pm 0.03 b$ & 5.92 & 0 & CAT1 (CATALASE 1); catalase \\
\hline
\end{tabular}

The relative quantitation of gene expression was conducted via the $2^{-\Delta \Delta \mathrm{Ct}}$ method, with actin as an endogenous reference. Data from three biological replicates were used to calculate the mean and standard deviation in DPS based on Student's t-test. Values followed by different letters indicate significant difference at $P<0.05$. FPKM: the expected number of Fragments per Kilobase of transcript sequence per Millions base pairs sequenced

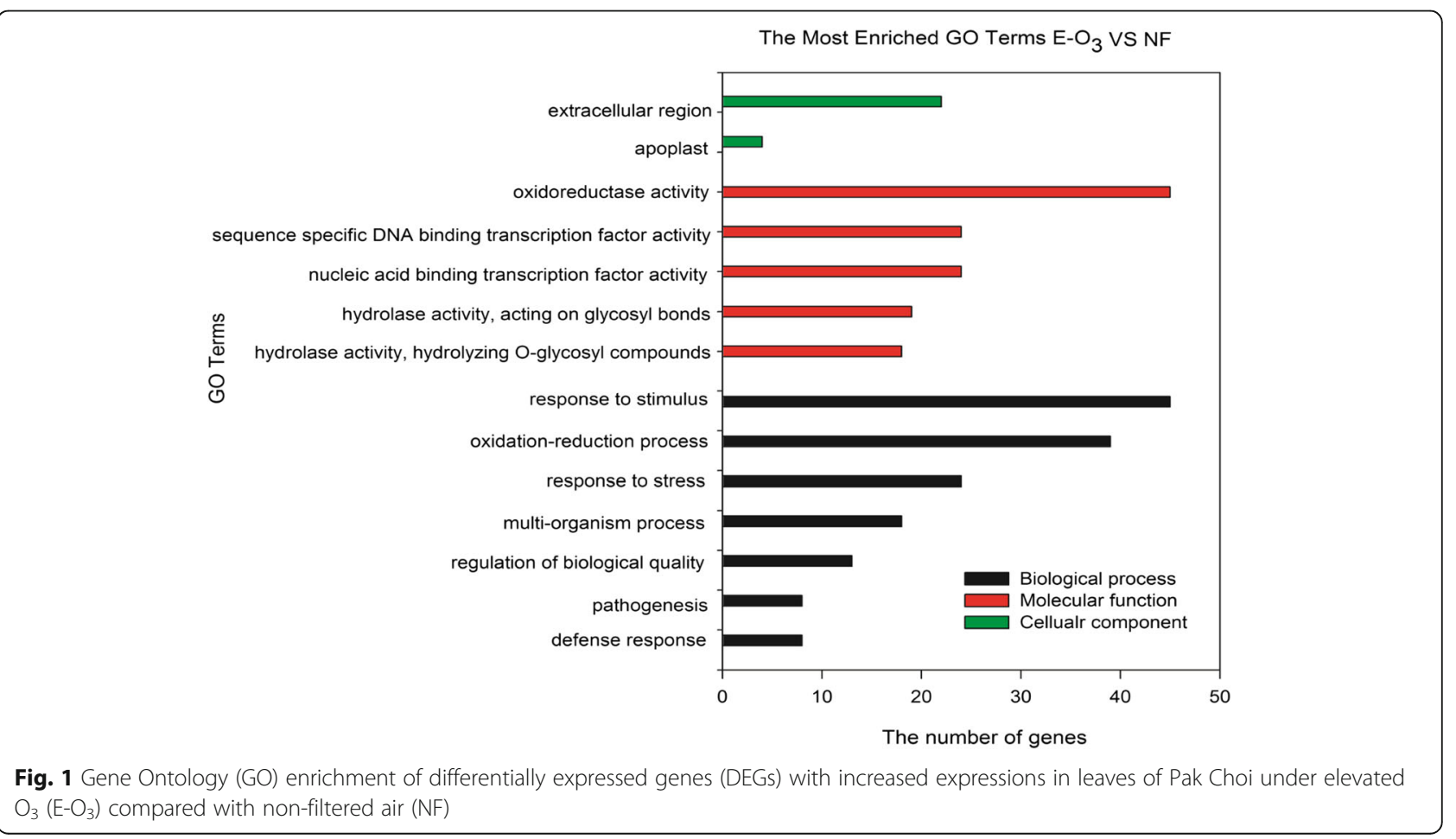




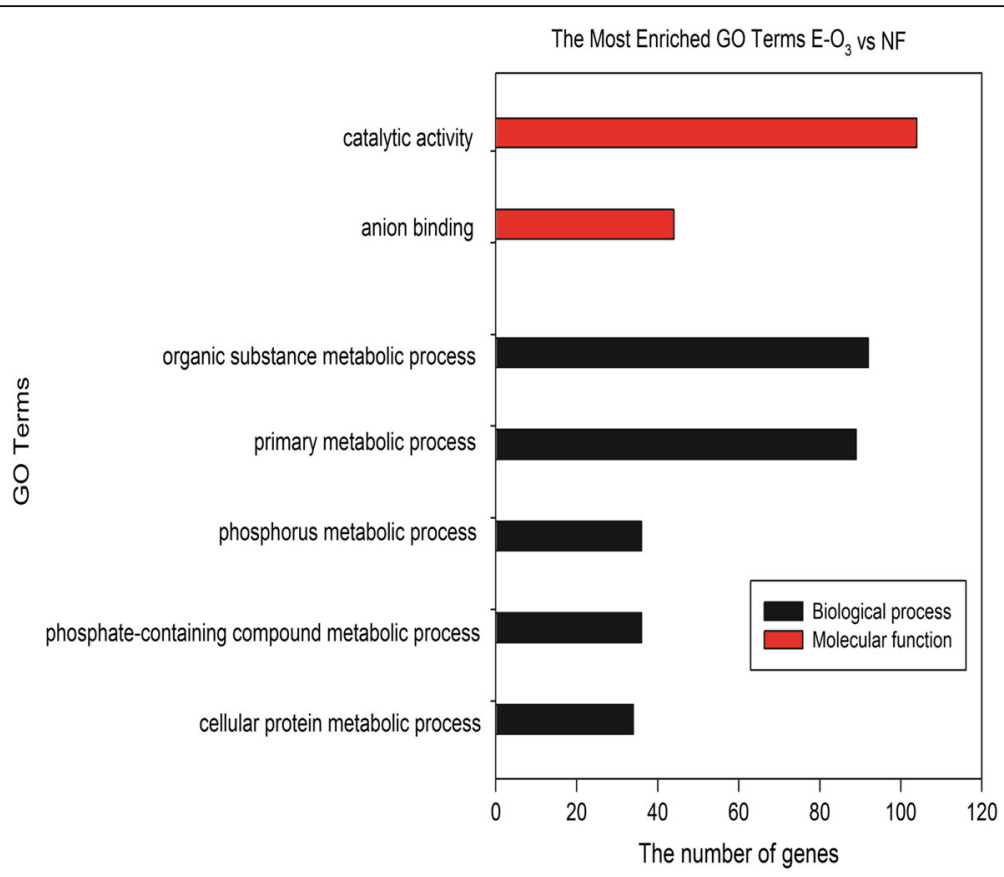

Fig. 2 Gene Ontology (GO) enrichment of differentially expressed genes (DEGs) with decreased expressions in leaves of Pak Choi under elevated $\mathrm{O}_{3}\left(\mathrm{E}-\mathrm{O}_{3}\right)$ compared with non-filtered air (NF)

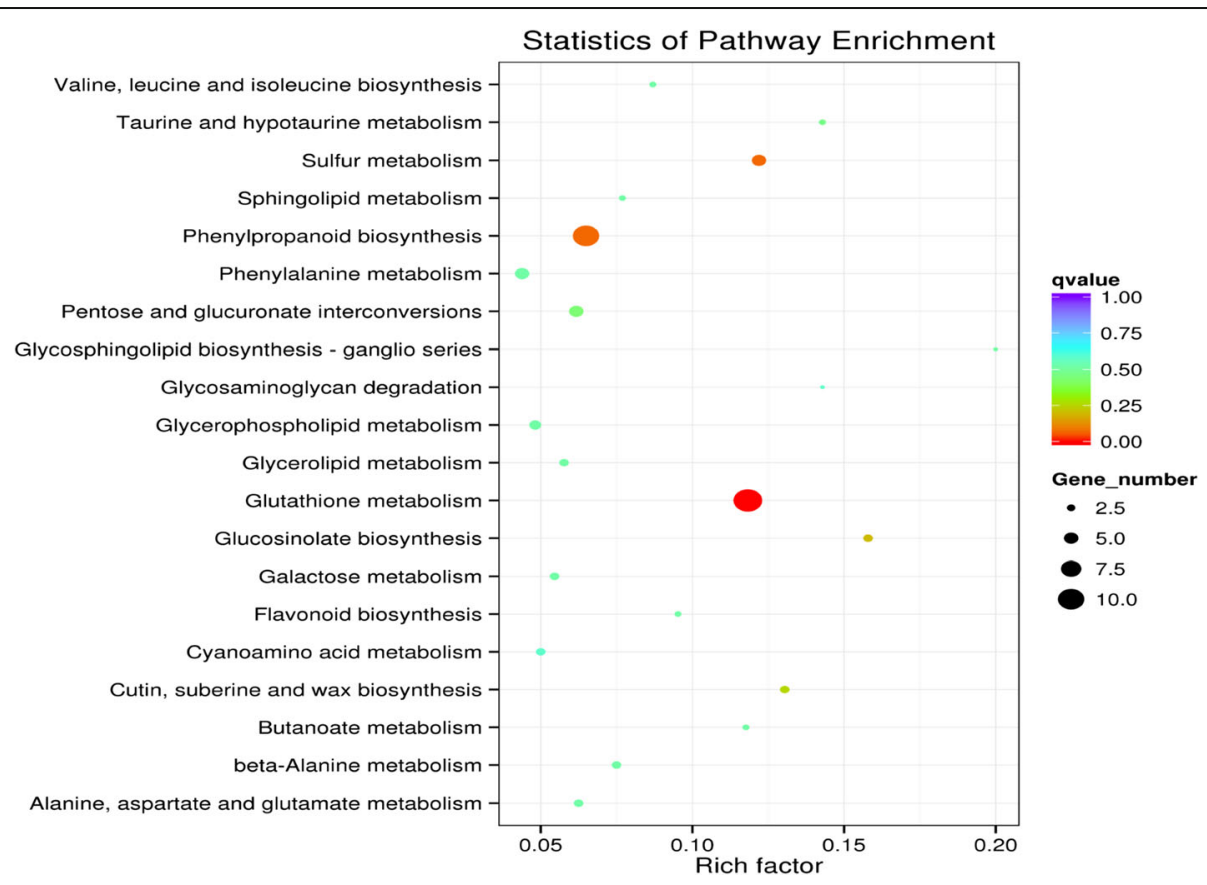

Fig. 3 Kyoto Encyclopedia of Genes and Genomes (KEGG) enrichment of differentially expressed genes (DEGs) with increased expressions in leaves of Pak Choi under elevated $\mathrm{O}_{3}\left(\mathrm{E}-\mathrm{O}_{3}\right)$ compared with non-filtered air (NF) 
Table 2 The expression patterns of related genes in the glutathione metabolism pathway under non-filtered air (NF) or elevated $\mathrm{O}_{3}$ $\left(\mathrm{E}-\mathrm{O}_{3}\right)$

\begin{tabular}{|c|c|c|c|}
\hline & & FPKM & \\
\hline Gene ID & Gene annotation & NF & $\mathrm{E}-\mathrm{O}_{3}$ \\
\hline Bra016250 & ATGSTU11 (GLUTATHIONE S-TRANSFERASE TAU 11); glutathione transferase & 192.79 & 640.92 \\
\hline Bra035029 & ATGSTU22 (GLUTATHIONE S-TRANSFERASE TAU 22); glutathione transferase & 0 & 31.89 \\
\hline Bra034061 & ATGSTU8 (GLUTATHIONE S-TRANSFERASE TAU 8); glutathione transferase & 58.71 & 1332.50 \\
\hline Bra039980 & $\begin{array}{l}\text { ATGSTU7 (Arabidopsis thaliana GLUTATHIONE S-TRANSFERASE TAU } \\
\text { 7); glutathione transferase }\end{array}$ & 365.32 & 1748.65 \\
\hline Bra025995 & $\begin{array}{l}\text { ATGSTU24 (GLUTATHIONE S-TRANSFERASE TAU 24); glutathione binding / } \\
\text { glutathione transferase }\end{array}$ & 59.65 & 1198.93 \\
\hline Bra025994 & ATGSTU25 (GLUTATHIONE S-TRANSFERASE TAU 25); glutathione transferase & 279.33 & 975.00 \\
\hline Bra039984 & $\begin{array}{l}\text { ATGSTU2 (ARABIDOPSIS THALIANA GLUTATHIONE S-TRANSFERASE TAU } \\
\text { 2); glutathione transferase }\end{array}$ & 1.18 & 21.17 \\
\hline Bra039982 & $\begin{array}{l}\text { ATGSTU4 (ARABIDOPSIS THALIANA GLUTATHIONE S-TRANSFERASE TAU } \\
\text { 4); glutathione transferase }\end{array}$ & 233.03 & 905.74 \\
\hline Bra026684 & ATGSTU25 (GLUTATHIONE S-TRANSFERASE TAU 25); glutathione transferase & 3.72 & 54.47 \\
\hline Bra026681 & ATGSTU25 (GLUTATHIONE S-TRANSFERASE TAU 25); glutathione transferase & 2.50 & 50.34 \\
\hline Bra032010 & ATGSTF11 (GLUTATHIONE S-TRANSFERASE F11); glutathione transferase & 305.56 & 564.83 \\
\hline
\end{tabular}

FPKM the expected number of Fragments per Kilobase of transcript sequence per Millions base pairs sequenced

'glycolysis/gluconeogenesis' [KEGGmap:ath00010], 'tryp tophan metabolism' [KEGGmap:ath00380], 'pyruvate metabolism' [KEGGmap:ath00620], and 'ether lipid metabolism' [KEGGmap:ath00565] (Fig. 7). Four DEGs were involved in 'carbon fixation in photosynthetic organisms', five were in 'glycolysis/gluconeogenesis' (Fig. 8), three were in 'tryptophan metabolism', four were in 'pyruvate metabolism', and two were in 'ether lipid metabolism'. Among them, some DEGs were involved in more than one metabolism pathway such as
Bra017856, Bra026068, Bra005526, Bra002822, and Bra009352.

Transcription factors (TFs) play key roles in the regulation of gene expression. Candidate $T F$ genes potentially involved in plant's responses to $\mathrm{O}_{3}$ stress were further analyzed (Table 3). The results showed that most of the DEGs encoding transcription factors that positively associated with stress-tolerance (e.g. AP2-EREBP, WRKY, Trihelix, MYB, C2H2, TAZ, LOB, SNF2 and PHD) had increased expressions in plants

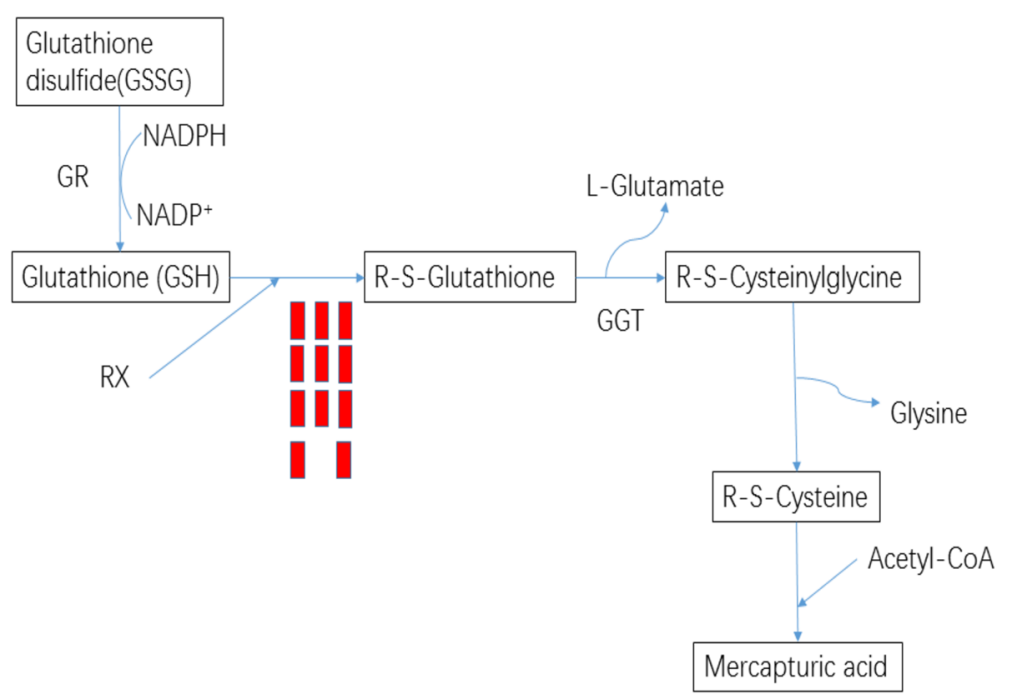

Fig. 4 Differential expressed genes predicted to be involved in the 'glutathione metabolism' pathway. Each red block means one DEG which had increased expression 


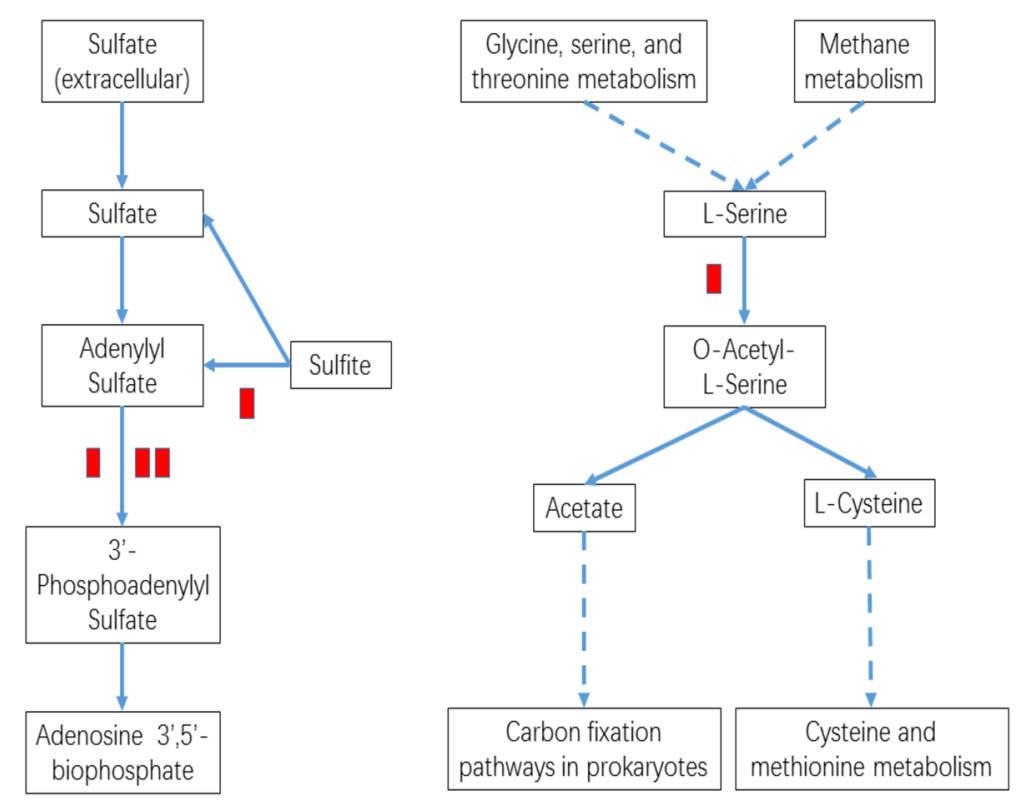

Fig. 5 Differential expressed genes predicted to be involved in the 'sulfur metabolism' pathway. Each red block means one DEG which had increased expression

under $\mathrm{E}-\mathrm{O}_{3}$; while there were only three $T F$ genes with decreased expressions encoding an Orphans protein (ARR15, negative regulator in cytokinin pathway), a bHLH family protein, and a Tify family protein under $\mathrm{E}-\mathrm{O}_{3}$ (Table 3 ).

\section{Discussion}

In the diet of human beings, leafy vegetables always play an important role. Ozone pollution may cause serious injury to leafy vegetables and result in great losses of productivity and quality [16]. In our previous study, $\mathrm{E}-\mathrm{O}_{3}$ caused visible injury and physiological alterations in Pak Choi but the molecular mechanism was not clear [19]. Previous reports showed that high $\mathrm{O}_{3}$ concentration triggers $\mathrm{O}_{3}$-responsive genes [20]. For examples, Ludwików et al. [9] reported the expression patterns of $\mathrm{O}_{3}$ stress-responsive Arabiodopsis genes with an

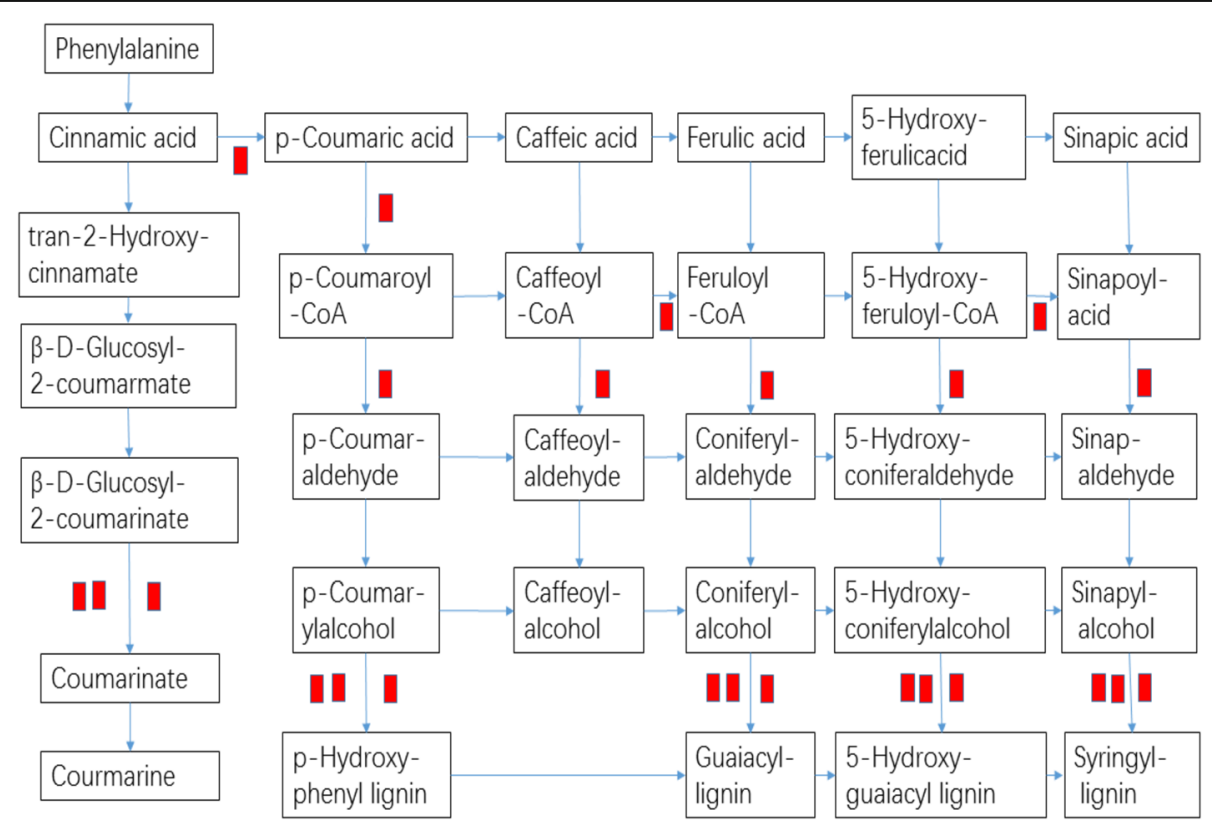

Fig. 6 Differential expressed genes predicted to be involved in the 'phenylpropanoid biosynthesis' pathway. Each red block means one DEG which had increased expression- 




Fig. 7 Kyoto Encyclopedia of Genes and Genomes (KEGG) enrichment of differentially expressed genes (DEGs) with decreased expressions in leaves of Pak Choi under elevated $\mathrm{O}_{3}\left(\mathrm{E}-\mathrm{O}_{3}\right)$ compared with non-filtered air (NF)

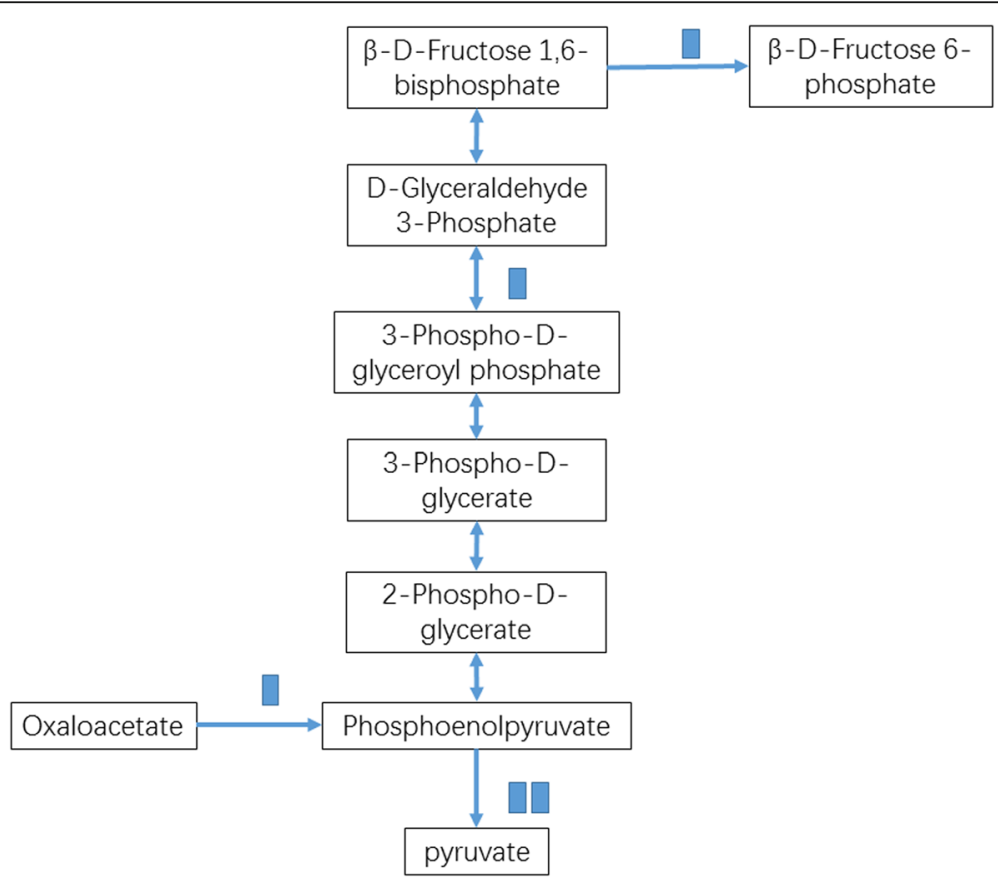

Fig. 8 Differential expressed genes predicted to be involved in 'glycolysis/gluconeogenesis' pathway. Each blue block means one DEG which had decreased expression 
Table 3 Selected genes of transcription factors with changed expressions under non-filtered air (NF) or elevated $\mathrm{O}_{3}\left(\mathrm{E}-\mathrm{O}_{3}\right)$

\begin{tabular}{|c|c|c|c|c|}
\hline & & & FPKM & \\
\hline Group & Gene ID & Gene Annotation & $\mathrm{E}-\mathrm{O}_{3}$ & NF \\
\hline \multirow[t]{2}{*}{ bHLH } & Bra000291 & DNA binding/ transcription factor & 3.40 & 19.54 \\
\hline & Bra011237 & basic helix-loop-helix (bHLH) family protein & 109.50 & 17.89 \\
\hline \multirow[t]{3}{*}{ Trihelix } & Bra005127 & Trihelix transcription factor GT-3b & 59.24 & 7.74 \\
\hline & Bra005688 & Trihelix transcription factor GT-3a & 85.79 & 5.53 \\
\hline & Bra028899 & transcription factor & 12.79 & 0 \\
\hline \multirow[t]{3}{*}{ WRKY } & Bra004370 & WRKY57 transcription factor & 18.79 & 4.263 \\
\hline & Bra036138 & WRKY48 transcription factor & 71.07 & 3.24 \\
\hline & Bra040926 & WRKY28 transcription factor & 86.83 & 3.15 \\
\hline MYB & Bra014929 & Myb-related protein Myb4 & 17.72 & 2.186 \\
\hline \multirow[t]{8}{*}{ AP2-ERF } & Bra012938 & Ethylene-responsive transcription factor ERF104 & 318.51 & 30.81 \\
\hline & Bra015660 & Ethylene-responsive transcription factor ERF013 & 25.10 & 7.60 \\
\hline & Bra019777 & $\begin{array}{l}\text { DDF1 (DWARF AND DELAYED FLOWERING } \\
\text { 1); DNA binding/ sequence-specific DNA binding/transcription factor }\end{array}$ & 37.12 & 2.12 \\
\hline & Bra024953 & $\begin{array}{l}\text { ERF5 (ETHYLENE RESPONSIVE ELEMENT BINDING FACTOR } \\
\text { 5); DNA binding/ transcription activator/ transcription factor }\end{array}$ & 203.15 & 28.95 \\
\hline & Bra026963 & $\begin{array}{l}\text { DDF1 (DWARF AND DELAYED FLOWERING 1); DNA binding/ } \\
\text { sequence-specific DNA binding/ transcription factor }\end{array}$ & 66.03 & 6.78 \\
\hline & Bra028290 & $\begin{array}{l}\text { CBF4 (C- REPEAT-BINDING FACTOR 4); DNA binding/ transcription } \\
\text { activator/ transcription factor }\end{array}$ & 74.88 & 1.76 \\
\hline & Bra035732 & AP2 domain-containing transcription factor, putative & 85.43 & 5.95 \\
\hline & Bra040158 & $\begin{array}{l}\text { ATERF6 (ETHYLENE RESPONSIVE ELEMENT BINDING FACTOR 6); DNA } \\
\text { binding/ transcription factor }\end{array}$ & 157.31 & 22.51 \\
\hline \multirow[t]{3}{*}{$\mathrm{C} 2 \mathrm{H} 2$} & Bra019477 & zinc finger ( $\mathrm{C} 2 \mathrm{H} 2$ type) family protein & 24.60 & 4.61 \\
\hline & Bra001752 & $\begin{array}{l}\text { AZF2 (ARABIDOPSIS ZINC-FINGER PROTEIN 2); DNA binding/ nucleic } \\
\text { acid binding/ transcription factor/ transcription repressor/ zinc ion binding }\end{array}$ & 152.39 & 18.96 \\
\hline & Bra020284 & $\begin{array}{l}\text { RHL41 (RESPONSIVE TO HIGH LIGHT 41); nucleic acid binding/ } \\
\text { transcription factor/ zinc ion binding }\end{array}$ & 22.37 & 4.41 \\
\hline Orphans & Bra015885 & $\begin{array}{l}\text { ARR15 (RESPONSE REGULATOR 15); negative regulator in the cytokinin-mediated } \\
\text { signal transduction in Arabidopsis }\end{array}$ & 3.05 & 14.43 \\
\hline \multirow[t]{2}{*}{ Tify } & Bra021923 & JAZ7 (JASMONATE-ZIM-DOMAIN PROTEIN 7) & 0 & 8.41 \\
\hline & Bra025713 & JAZ1 (JASMONATE-ZIM-DOMAIN PROTEIN 1); protein binding & 77.83 & 24.39 \\
\hline TAZ & Bra017839 & BT5 (BTB AND TAZ DOMAIN PROTEIN 5); protein binding/ transcription regulator & 24.37 & 4.69 \\
\hline LOB & Bra011942 & LBD11 (LOB DOMAIN-CONTAINING PROTEIN 11) & 41.51 & 4.21 \\
\hline SNF2 & Bra023689 & $\begin{array}{l}\text { CHR17 (CHROMATIN REMODELING FACTOR17); ATP binding / DNA binding/ } \\
\text { DNA-dependent ATPase/ helicase/ hydrolase, acting on acid anhydrides, in } \\
\text { phosphorus-containing anhydrides/ nucleic acid binding/ nucleosome binding }\end{array}$ & 10.49 & 0.62 \\
\hline PHD & Bra027316 & PHD finger family protein & 6.96 & 0 \\
\hline
\end{tabular}

FPKM the expected number of Fragments per Kilobase of transcript sequence per Millions base pairs sequenced

emphasis on ROS-scavenging (e.g. catalase genes) and secondary metabolism (e.g. phenylpropanoid-related genes); Mahalingam et al. [21] classified $\mathrm{O}_{3}$-responsive genes into down-regulated (e.g. coding for proteins that function in chloroplast), early up-regulated (e.g. coding for membrane proteins and those involved in transcription and signaling), and late up-regulated genes (e.g. coding for membrane-associated or secretory proteins, and those involved in ROS-scavenging). In aspen trees, the genes related to defense and signaling were up-regulated while the genes in the carbohydrate metabolism were downregulated [15]. Ludwików et al. [8] summarized the possible functions of differential expressed genes under $\mathrm{O}_{3}$ stress into several groups as follows: redox control, transcription, signal transduction, metabolism, and defense.

In this study, transcriptomic profiles of Pak Choi under NF or $\mathrm{E}_{-} \mathrm{O}_{3}$ were compared using RNA-Seq technology for the first time. It is noteworthy that the experiment was designed to simulate an acute $\mathrm{O}_{3}$ exposure according to realistic $\mathrm{O}_{3}$ concentrations in relatively 
clear area and in a highly $\mathrm{O}_{3}$-polluted area or a projected future $[22,23]$. Based on the results of our previous physiological study with this species [19], we postulated that 2 days were sufficient to analyze the $\mathrm{O}_{3}$-responsive genes in Pak Choi. The current results not only characterized the essential key genes, but also unveiled potential metabolic pathways or TFs that are potentially involved in cellular regulation or adaptation against $\mathrm{O}_{3}$ stress. According to $\mathrm{GO}$ enrichment analysis, potential functions of DEGs under $\mathrm{O}_{3}$ stress have been summarized in several aspects, such as redox control, defense, transcription, signal transduction, and metabolism [8]. In this study, we found that the DEGs between $\mathrm{E}_{-} \mathrm{O}_{3}$ and NF were mainly related to defense, redox control and metabolism.

In particular, for the DEGs with increased expressions in plants under $\mathrm{E}-\mathrm{O}_{3}$, the most enriched ones were 'response to stimulus', 'oxidation-reduction process', 'response to stress', 'pathogenesis' and 'oxidoreductase activity'. The enrichment of genes which related to 'pathogenesis' indicated the similarity between plant response to $\mathrm{O}_{3}$ and pathogen infection, as both of these stresses triggered the production of ROS [24]. This result is consistent with the other reports in which pathogenesis-related (PR) proteins were induced by $\mathrm{O}_{3}$ $[13,25-27]$.

Ozone enters the leaves and subsequently triggers the production of ROS that leads to activation of ROS scavenging systems [6-8]. In our previous study, we showed that $\mathrm{O}_{3}$ treatment caused enhanced antioxidant enzyme activities in Pak Choi [19]. ROS are signaling molecules that often result in cell wall strengthening. In this study, cell wall-related genes were also found with increased expressions under $\mathrm{O}_{3}$ treatment. For example, xyloglucan endotransglycosylase (XETs) played key roles in repairing the damage of cell caused by $\mathrm{O}_{3}$ attack, promoting cell wall biogenesis and increasing cell or stomatal density. Our result showed that the expressions of XET coding genes increased in response to $\mathrm{O}_{3}$, which was consistent with previous reports [28-31], suggesting that cell wall modification is a common strategy for plant to adapt to high $\mathrm{O}_{3}$.

Previous reports showed that the expressions of some genes in 'oxidation-reduction process' or with 'oxidoreductase activity' increased in response to $\mathrm{O}_{3}$ stress in different plant species [4,32-35], and similar results were observed with Pak Choi in this study. Proteomic analysis in poplar also showed that two enzymes with oxidoreductase activity increased under $\mathrm{O}_{3}$ exposure [36]. These activated oxidoreductase genes potentially function to avoid severe oxidative damage at the cellular level. Furthermore, KEGG pathway analysis also revealed significantly increased expressions of genes involved in the glutathione metabolism. Glutathione S-transferases
(GSTs) have functions in preventing oxidative damage and keeping redox homeostasis [37-40]. Our results showed that the expression of DEGs encoding GSTs increased, suggesting that GSTs were involved in protecting the cell against $\mathrm{O}_{3}$ stress in this experiment. In addition, expressions of genes (Bra025351 and Bra039047) homologous to CYP81D11, which putatively encodes cytochrome P450 monooxygenases, increased in the present study. It has been reported that expression of CYP81D11 could be induced by osmotic stresses, ABA-, SA- and JA-treatments that the gene probably played important roles in plant detoxification processes $[41,42]$. Furthermore, cytochrome P450 monooxygenases might be conjugated to glutathione or sugar moieties by either glutathione S-transferases or glycosyl transferases, and then the conjugates were transported to the apoplast or vacuole [43]. The higher expression of GST genes and the GO enrichment in 'extracellular region' or 'apoplast' probably revealed the detoxification processes of Pak Choi to $\mathrm{O}_{3}$ stress.

Oxidation of membrane lipid in the presence of ROS could lead to accumulation of omega-3 trienoic fatty acids (TFAs) that was the primary precursor of jasmonic acid (JA), one important phytohormone for defense [44-46]. As a feedback reaction, jasmonic acid (JA) acts to limit $\mathrm{O}_{3}$-lesion spread [7]. In the oxidative cell death cycle, jasmonates protect tissues from ROS-induced cell death and thus counteract the effects of salicylic acid and ethylene [7]. In the present study, the expression level of one putative JAZ7 encoding gene (Bra021923), which belonged to Tify family protein, was silenced when under $\mathrm{O}_{3}$ treatment. Yu et al. [47] reported that mutation of JAZ7 in the darkness might cause the up-regulation of the genes involved in sulphate metabolism, indole-glucosinolate biosynthesis, callose deposition, and JA-mediated signaling pathways. While the expression of gene (Bra025713) encoding JAZ1 protein, which acts to repress JA signaling, increased in this study [48, 49]. Our results of KEGG enrichment showed that the expressions of DEGs related to 'sulfur metabolism' and 'glucosinolate biosynthesis' increased, suggesting the JAZ7 and JAZ1 were both involved in $\mathrm{O}_{3}$ stress responses and might play opposite functions. This result indicated that $\mathrm{O}_{3}$ stress potentially activated JA-responsive genes and limited the spread of leaf cell death lesions to protect the healthy tissue, which was confirmed by the observation of foliar visible injury in our previous study [19].

In perceiving the $\mathrm{O}_{3}$ stress signals as well as JA signal, plants employ multifaceted signaling pathways to regulate their cellular responses. In this study, defenserelated signaling kinase genes and transcription factor genes were also revealed in response to $\mathrm{O}_{3}$ stress. For example, the expression of a SnRK2 family serine/ 
threonine-protein kinase gene (Bra015981) increased [50]. The expressions of a number of defense-related AP2/ERF, Trihelix, WRKY, and MYB family genes also increased in response to $\mathrm{O}_{3}$ stress. It has been documented that members of the AP2/ERF family confer tolerance to multiple stresses $[51,52]$ and are key regulators of redox responsive gene networks [53]. In the present study, we also found that most of the DEGs encoding AP2/ERF family proteins had increased expression levels. Among them, Bra024953 encoding ERF5 had a higher expression level upon $\mathrm{E}_{-} \mathrm{O}_{3}$ than in NF. This result is also consistent with other previous studies [54]. In tomato, expression of ERF5 was induced by abiotic stress, such as drought, wounding etc. [55]. It seems that the up regulation of ERF5 is a common response to abiotic stresses. CBF4 is a regulator for adapting to drought stress [56]. Our results showed that this TF might also be involved in the response to $\mathrm{O}_{3}$ in Pak Choi.

Trihelix family genes play important roles in plant development, but their responses to abiotic stresses are indistinct to date [57]. Only a few Trihelix family genes were found responsive to abiotic stress such as cold or salt in Brassica species [57, 58]. For the first time, we found that the expressions of Trihelix family genes, Bra005127, Bra005688, and Bra028899, increased in Pak Choi when exposed to high $\mathrm{O}_{3}$ concentration. In particular, Bra005688 encoded GT-3a ortholog, which has a function in binding GTTAC and is light inducible [59]. GT-3b, which is encoded by Bra005127 can be induced by pathogen or salt stress $[59,60]$. Our result suggested that these two TFs potentially played important roles in $\mathrm{O}_{3}$ stress regulation.

WRKY proteins with conserved WRKY motif and zinc finger-like domain function as transcriptional activators or repressors [61]. WRKY TFs have been found to be responsive to abiotic stresses such as $\mathrm{O}_{3}$ [62-64]. In this study, three DEGs encoding WRKY family proteins were identified and the expressions of them increased under $\mathrm{E}-\mathrm{O}_{3}$ exposure. WRKY transcription factors were involved in the regulation of senescence-related processes $[20,62,65]$. It has been reported that 22 Pak Choi WRKY genes were differentially expressed in response to abiotic stresses, such as cold and salinity. [66]. In the present study, we found three new DEGs encoded WRKY28, WRKY48, and WRKY57, respectively, and were probably specifically related to $\mathrm{O}_{3}$ stress response.

The induction of MYBs also mediated transcriptional reprogramming in response to ${\mathrm{E}-\mathrm{O}_{3}}_{3}[62,64,67]$. MYBs could regulate the genes related to anthocyanin biosynthesis pathway and the JAZ-DELLA-MYBL2 module upstream of the MYB/bHLH/WD40 complex together mediated abiotic stress-caused anthocyanin accumulation in Arabidopsis [68]. Our results also showed that the expression of one gene encoding MYB family protein increased, which coincided with the accumulation of anthocyanin in $\mathrm{O}_{3}$-treated Pak Choi [19].

The other down-stream functional genes, besides those stated above (e.g. XETs \& GST), also includes genes involved in sulfur metabolism and phenylpropanoid biosynthesis. Kimura et al. [69] reported that SnRK2.3, which enzyme's putative encoding gene had increased expression, controls the production of $\mathrm{O}$-acetylL-serine a putative signaling compound of the sulfur starvation response, and our KEGG enrichment result showed that the expression of DEG (Bra038031) encoded the enzyme catalyzing L-serine to O-acetyl-Lserine in the 'sulfur metabolism' pathway increased. These two genes (Bra015981 and Bra038031) probably work together under the $\mathrm{O}_{3}$ caused sulfur starvation, among which Bra038031 encoded the enzyme catalyzing L-serine to O-acetyl-L-serine and Bra010645 encoded the enzyme catalyzing adenylyl sulfate to 3 '-phosphoadenylyl sulfate.

The expressions of ten DEGs in 'phenylpropanoid biosynthesis' pathway increased. Proteins encoded by Bra037007 and Bra009105 were involved in catalyzing the alcohol to lignin. There were two DEGs which played a key role in catalyzing $\beta$-D-glucosyl-2-coumarinate into coumarinate. Flavonoid is a derivative product of the phenylpropanoid biosynthesis pathway. The TRANSPARENT TESTA 12 (TT12) encodes a multidrug and toxic compound extrusion (MATE) vacuolar transporter that is required for flavonoid sequestration in developing seed coat of Arabidopsis [70]. Chai et al. [71] found that the TT12 is less organ-specific and also expressed in leaves of Brassica. Our result showed that the gene (Bra020862) with increased expression and homologous to AtTT12 in the leaves of Pak Choi was probably involved in the defense to $\mathrm{O}_{3}$ stress.

We also found that PR protein increased with the increasing expression of genes encoding GST. Plasmodesmata callose-binding protein 2 (PDCB2) is identified as a glycosylphosphatidylinositol (GPI)-anchor protein [72]. In the present study, the expression of DEG encoding PDCB2 increased under $\mathrm{E}_{-} \mathrm{O}_{3}$, suggesting that callose deposition might be enhanced, and cell to cell communication could be inhibited in $\mathrm{O}_{3}$ stressed Pak Choi [73].

The most enriched pathway of genes with decreased expression was 'glycolysis/gluconeogenesis'. Some DEGs in this pathway were also involved in 'carbon fixation in photosynthetic organisms' and 'pyruvate metabolism' pathway. The lower biosynthesis of phosphoenolpyruvate from oxaloacetate, and D-Fructose 6-phosphate from D-Fructose 1, 6-bisphosphate were probably the main reasons for the impairment of photosynthesis and respiration under $\mathrm{E}_{-} \mathrm{O}_{3}$. 


\section{Conclusion}

RNA-Seq was performed for Pak Choi plants exposed to $\mathrm{NF}$ and high $\mathrm{O}_{3}$ concentration. The transcriptomic comparison together with physiological analysis (published in [19]) revealed that $\mathrm{O}_{3}$ treatment led to ROS burst and then resulted in lipid oxidation and hormonal (esp. JA) signaling alterations. The signal transduction via phosphorylation (e.g. SnRK2 family kinases) ultimately affected the expression of defense-related transcription factors and down-stream stress-related functional genes (e.g. $P R$ genes, $P D C B 2$ gene, sulfur metabolism and phenylpropanoid biosynthesis-related genes). The proposed working model for acute $\mathrm{O}_{3}$-stress signaling network was illustrated in Fig. 9. This result suggested that ROS metabolism, JA pathway and associated downstream functional genes worked together to maintain cellular homeostats and adaptation to $\mathrm{O}_{3}$ stress. The regulation of plant gene expression included multiple regulatory steps beyond transcriptional regulation; and the current result provided an overall, but not a complete, insight into $\mathrm{O}_{3}$ effect on Pak Choi. The specific DEGs coding for transcription factors, kinase and functional proteins could be valuable targets for genetic manipulation to improve the $\mathrm{O}_{3}$ stress tolerance of Pak Choi through experimental approaches in the future.

\section{Methods}

\section{Plant material and treatments}

One commonly cultivated variety of Pak Choi ('Jingguan') was selected in this study. Seeds were from Beijing Vegetable Research Center, Beijing Academy of Agriculture and Forestry Sciences. The seeds were sown in pots (10 $\mathrm{cm}$ in diameter), filled with a mixture of peat:vermiculite (3:1,v:v) at $25{ }^{\circ} \mathrm{C}$ in a greenhouse in July 2015 . When they had five leaves in total, 20 seedlings were moved into open top chambers (OTCs) for $\mathrm{O}_{3}$ treatments.

The OTCs were located in Changping cropland area $\left(40^{\circ} 19^{\prime} \mathrm{N}, 116^{\circ} 13^{\prime} \mathrm{E}\right)$, Beijing. Details on the OTCs are in Yuan et al. [74]. After 2 days' adaption to OTC, 20 randomly-picked plants were moved into either of two OTCs. One OTC was fumigated with elevated $\mathrm{O}_{3}\left(\mathrm{E}-\mathrm{O}_{3}\right)$ and the other one with non-filtered air (NF). Ozone was generated using pure oxygen by a generator and mixed with ambient air using a fan according to $\mathrm{Hu}$ et al. [75]. Ozone concentrations at approximately $10 \mathrm{~cm}$ above the plant canopy within the OTCs were continuously

Model for cellular response to $\mathrm{O}_{3}$ stress in Pak Choi (Red arrows represent up-regulation, while green arrow represents down-regulation when under $\mathrm{O}_{3}$ stress )

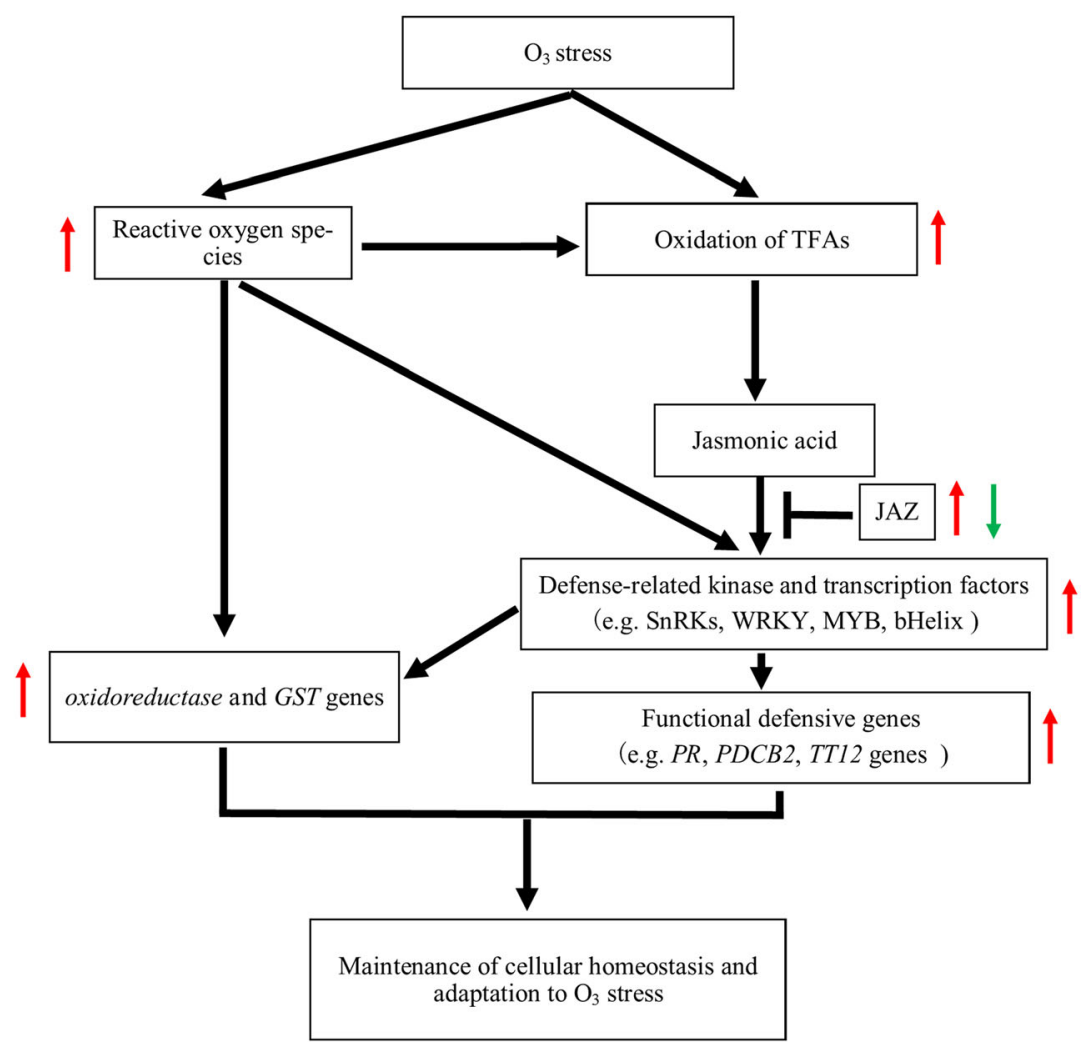

Fig. 9 Proposed working model for acute $\mathrm{O}_{3}$-stress signaling network in Pak Choi 
measured using an $\mathrm{O}_{3}$ analyzer (Model 49i, Thermo Scientific, USA). Plants were fumigated for 2 days (8 h per day, from 9:00-17:00) on 21st and 22nd August 2015, and the ozone metrics were calculated as AOT40 (the sum of the differences between hourly $\mathrm{O}_{3}$ concentrations and $40 \mathrm{ppb}$ for each hour when the concentration is above $40 \mathrm{ppb}$ during daylight hours) according to CLRTAP [76]. In NF, the $16 \mathrm{~h}$ mean $\mathrm{O}_{3}$ concentration was $30.79 \pm 1.85 \mathrm{ppb}$, the maximum hourly $\mathrm{O}_{3}$ concentration was $42.60 \mathrm{ppb}$, and AOT40 was $0.004 \mathrm{ppm} \cdot \mathrm{h}$ (Additional file 5: Table S2). Under $\mathrm{E}_{-} \mathrm{O}_{3}$ exposure, the $16 \mathrm{~h}$ mean $\mathrm{O}_{3}$ concentration was $251.71 \pm 8.15 \mathrm{ppb}$, the maximum hourly $\mathrm{O}_{3}$ concentration was $318.75 \mathrm{ppb}$, and AOT40 was $3.39 \mathrm{ppm} \cdot \mathrm{h}$ (Additional file 5: Table S2). At the end of the exposure, three biological replicates (plants) in each treatment were randomly selected for the following RNA-Seq analysis.

\section{RNA extraction and library preparation for transcriptome analysis}

The second leaves from the top were sampled from three plants in each treatment, immediately frozen in liquid nitrogen for RNA preparation. Three $\mu \mathrm{g}$ RNAs per sample were used to generate sequencing libraries using the NEBNext ${ }^{\circ}$ Ultra ${ }^{\mathrm{am}}$ RNA Library Prep Kit for Illumina ${ }^{\circ}$ (NEB, USA). In brief, mRNA was isolated with poly- $\mathrm{T}$ oligo-attached magnetic beads, fragmented using NEBNext First Strand Synthesis Reaction Buffer (5X), and then reverse transcribed into first and second strand cDNA using random hexamer primer by M-MuLV Reverse Transcriptase (RNase $\mathrm{H}^{-}$) and DNA Polymerase I, respectively. The residual mRNA was removed by RNase $\mathrm{H}$. The remaining overhangs were converted into blunt ends via exonuclease/polymerase activities, and adenylated at the 3' ends with NEBNext Adaptor with a hairpin loop structure. Furthermore, the AMPure XP system (Beckman Coulter, Beverly, USA) was used to select 150 200 bp cDNA fragments. Then $3 \mu \mathrm{l}$ USER Enzyme (NEB, USA) was used with adaptor-ligated, size-selected cDNA for $15 \mathrm{~min}$ at $37{ }^{\circ} \mathrm{C}$ followed by 5 min at $95{ }^{\circ} \mathrm{C}$ before PCR with Phusion High-Fidelity DNA polymerase, Universal PCR primers and Index (X) Primer. Finally, PCR products were purified in AMPure XP system and the library quality was assessed on the Agilent Bioanalyzer 2100 system. The obtained libraries were sequenced on an Illumina Hiseq 2500 platform to generate $125 \mathrm{bp}$ paired-end reads.

\section{Analysis of Illumina sequencing results}

In order to obtain clean data (clean reads), low quality reads, reads containing adapters, and reads containing poly-N of raw data were erased. After that Q20, Q30, GC-content of the clean data were calculated. Based on high quality clean data, the following analyses were conducted.

\section{Quantification of gene expression levels and differential expression analysis}

The reference genome and gene model annotation files of Brassica were from its database website (http://brassicadb.org/brad/) [77]. Using TopHat (v2.0.12), clean data were mapped back onto the reference genome. The reads numbers mapped to each gene were calculated using the HTSeq (v0.6.1). The expected number of Fragments per Kilobase of transcript sequence per Millions base pairs sequenced (FPKM) of each gene was estimated based on reads numbers mapped to this gene and the gene length. Differentially expressed genes (DEGs) of plants under different treatments (three biological replicates per treatment) were identified by DESeq $(P<0.05$, $\mid \log _{2}$ (fold change) $\left.\mid>0.8\right)$ [78]. Based on Wallenius non-central hyper-geometric distribution, Gene Ontology $(\mathrm{GO})$ enrichment analysis $(P<0.05)$ of the DEGs was conducted by the GO seq $R$ packages [79]. The statistical analysis $(P<0.05)$ of DEGs enrichment in Kyoto Encyclopedia of Genes and Genomes (KEGG) pathways was conducted using KOBAS 2.0 [80].

\section{Real-time quantitative RT-PCR (qRT-PCR) assay}

Using qRT-PCR, the expression patterns of 12 genes (Gene ID: Bra003517, Bra013923, Bra020878, Bra028899, Bra031485, Bra038089, Bra034061, Bra035732, Bra010802, Bra012938, Bra00944, and Bra025833) were analyzed (Primers are listed in Additional file 6: Table S3). Actin was used as the reference gene according to [81]. In brief, cDNA was synthesized using ReverseTra Ace qPCR-RT Kit (Toyobo, Japan). The reverse transcription reaction system included $0.5 \mu \mathrm{L}$ primer mix, $2 \mu \mathrm{L}$ RNA template, $0.5 \mu \mathrm{L}$ RT enzyme mix, $2 \mu \mathrm{L} 5 \times \mathrm{RT}$ buffer, $5 \mu \mathrm{L} \mathrm{dd}_{2} \mathrm{O}$. In reference to the corresponding unigene sequence, gene-specific primers were designed using the online tool [GenScript Real-time PCR (TaqMan) Primer Design, https://www.genscript.com/ssl-bin/app/primer]. And the efficiency of the primer pairs were checked by serial dilutions of template cDNA as shown in Additional file 7: Figure S3. The cDNA

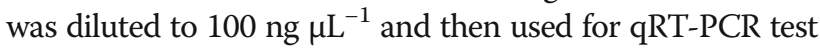
with each gene-specific primers and $\mathrm{SYBR}^{\circ}$ Green Real time PCR Master Mix (Toyobo, Japan) on the Bio-Rad iQ5 real time system. Reactions were conducted at $96{ }^{\circ} \mathrm{C}$ for $1 \mathrm{~min}, 40$ cycles of $95{ }^{\circ} \mathrm{C}$ for $15 \mathrm{~s}, 60{ }^{\circ} \mathrm{C}$ for $15 \mathrm{~s}$ and $72{ }^{\circ} \mathrm{C}$ for $45 \mathrm{~s}$.

\section{Data analysis}

qRT-PCR was conducted for each gene expression analysis using three biological replicates per treatment. The 
$16 \mathrm{~h}$ mean $\mathrm{O}_{3}$ concentration were calculated using $1 \mathrm{~h}$ average $\mathrm{O}_{3}$ concentration as replicate. Mean value and standard deviation were calculated in DPS based on Student's t-test. The relative quantitation of gene expression of qRT-PCR was measured via the $2^{-\Delta \Delta C t}$ method [82], with actin as the endogenous reference gene.

\section{Additional files}

Additional file 1: Table S1. Summary of sequences analysis and RNA-Seq data. (DOCX $17 \mathrm{~kb}$ )

Additional file 2: Figure S1. The quality of raw reads of Pak Choi under elevated $\mathrm{O}_{3}\left(\mathrm{E}-\mathrm{O}_{3}\right)$ and non-filtered air (NF) using RNA-Seq. (TIFF $1648 \mathrm{~kb}$ )

Additional file 3: Figure S2. The principle component analysis (PCA) of the reads of Pak Choi under elevated $\mathrm{O}_{3}\left(\mathrm{E}-\mathrm{O}_{3}\right)$ and non-filtered air (NF) using RNA-Seq. (TIFF $80 \mathrm{~kb}$ )

Additional file 4: Differentially expressed genes (DEGs) in Pak Choi under two $\mathrm{O}_{3}$ exposure. (XLSX $61 \mathrm{~kb}$ )

Additional file 5: Table S2. Ozone concentrations in non-filtered air (NF) and elevated ozone (E-O $\mathrm{O}_{3}$ ) exposure. (DOCX $15 \mathrm{~kb}$ )

Additional file 6: Table S3. The primers used for qRT -PCR. (DOC $33 \mathrm{~kb}$ ) Additional file 7: Figure $\mathbf{S 3}$. Effciency of primer pairs used in the qRT-PCR analysis. (TIFF $1374 \mathrm{~kb}$ )

\section{Abbreviations}

bHLH: basic Helix-Loop-Helix; DEGs: Differentially expressed genes; E$\mathrm{O}_{3}$ : Elevated $\mathrm{O}_{3}$; FPKM: the expected number of Fragments per Kilobase of transcript sequence per Millions base pairs sequenced; GO: Gene Ontology; GSTs: Glutathione S-transferases; JA: Jasmonic acid; KEGG: Kyoto Encyclopedia of Genes and Genomes; NF: Non-filtered air; OTCs: Open top chambers; qRTPCR: Real-time quantitative PCR; ROS: Reactive oxygen species

\section{Acknowledgements}

We thank Dr. Yanfang Yang and Mr. Zaisheng Shao for their help during the experiment.

\section{Funding}

This study was financially supported by National Natural Science Foundation of China (31401895) and 'Young Talents' project of Northeast Agricultural University of China (14Q10).

\section{Availability of data and materials}

The raw RNA-Seq data for the Pak Choi under two $\mathrm{O}_{3}$ concentrations each with three replicates are available in the NCBI Sequence Read Archive (SRA) repository via accession number SRP100739.

\section{Authors' contributions}

LZ designed the experiments; LZ and ZF conducted the ozone treatment; LZ and BX performed the RNA-Seq and data analysis; TW, MW, and LF performed qRT-PCR measurement and analysis; LZ, BX and EP wrote the manuscript. All authors have read and approved the final manuscript.

\section{Ethics approval and consent to participate}

Not applicable.

\section{Consent for publication}

Not applicable.

\section{Competing interests}

The authors declare that they have no competing interests.

\section{Publisher's Note}

Springer Nature remains neutral with regard to jurisdictional claims in published maps and institutional affiliations.

\section{Author details}

${ }^{1}$ College of Horticulture and Landscape Architecture, Northeast Agricultural University, Harbin, China. ${ }^{2}$ College of Agro-grassland Science, Nanjing Agricultural University, Nanjing, China. ${ }^{3}$ State Key Laboratory of Urban and Regional Ecology, Research Center for Eco-Environmental Sciences, Chinese Academy of Sciences, Beijing, China. ${ }^{4}$ Institute of Sustainable Plant Protection, National Research Council, Florence, Italy.

Received: 9 April 2017 Accepted: 1 December 2017

Published online: 08 December 2017

\section{References}

1. Hough AM, Derwent RG. Changes in the global concentration of tropospheric ozone due to human activities. Nature. 1990;344:645-8.

2. Ainsworth EA, Yendrek CR, Sitch S, Collins WJ, Emberson LD. The effects of tropospheric ozone on net primary productivity and implications for climate change. Annu Rev Plant Biol. 2012;63:637-61.

3. Feng Z, Sun J, Wan W, Hu E, Calatayud V. Evidence of widespread ozone induced visible injury on plants in Beijing, China. Environ Pollut. 2014;193: 296-301.

4. Baier M, Kandlbinder A, Golldack D, Dietz KJ. Oxidative stress and ozone: perception, signalling and response. Plant Cell Environ. 2005;28:1012-20.

5. Paoletti E. Ozone impacts on forests. CAB Reviews: Perspectives in Agriculture, Veterinary Science, Nutrition and Natural Resources. 2007;2:1-13.

6. Wohlgemuth H, Mittelstrass K, Kschieschan S, Bender J, Weigel HJ, Overmyer K, Kangasjärvi J, Sandermann H, Langebartels C. Activation of an oxidative burst is a general feature of sensitive plants exposed to the air pollutant ozone. Plant Cell Environ. 2002;25:717-26.

7. Kangasjärvi J, Jaspers P, Kollist H. Signaling and cell death in ozone-exposed plants. Plant Cell Environ. 2005;28:1021-36.

8. Ludwików A, Sadowski J. Gene networks in plant ozone stress response and tolerance. J Integr Plant Biol. 2008;50:1256-67.

9. Ludwików A, Gallois P, Sadowski J. Ozone-induced oxidative stress response in Arabidopsis: transcription profiling by microarray approach. Cell Mol Biol Lett. 2004:9:829-42.

10. Mahalingam R, Jambunathan N, Gunjan SK, Faustin E, Weng H, Ayoubi P. Analysis of oxidative signaling induced by ozone in Arabidopsis thaliana. Plant Cell Environ. 2006;29:1357-71.

11. Xu E, Vaahtera L, Hõrak H, Hincha DK, Heyer AG, Brosché M. Quantitative trait loci mapping and transcriptome analysis reveal candidate genes regulating the response to ozone in Arabidopsis thaliana. Plant Cell Environ. 2015;38:1418-33.

12. Puckette MC, Tang Y, Mahalingam R. Transcriptomic changes induced by acute ozone in resistant and sensitive Medicago truncatula accessions. BMC Plant Biol. 2008:8:46

13. Lee S, Yun SC. The ozone stress transcriptome of pepper (Capsicum Annuum L.). Mol Cell. 2006;21:197-205.

14. Whaley A, Sheridan J, Safari S, Burton A, Burkey K, Schlueter J. RNA-seq analysis reveals genetic response and tolerance mechanisms to ozone exposure in soybean. BMC Genomics. 2015;16:1.

15. Gupta P, Duplessis S, White H, Karnosky DF, Martin F, Podila GK. Gene expression patterns of trembling aspen trees following long-term exposure to interacting elevated $\mathrm{CO}_{2}$ and tropospheric $\mathrm{O}_{3}$. New Phytol. 2005;167:129-42.

16. González-Fernández I, Elvira S, Calatayud V, Calvo E, Aparicio P, Sánchez M, Alonso R, Bermejo VB. Ozone effects on the physiology and marketable biomass of leafy vegetables under Mediterranean conditions: spinach (Spinacia Oleracea L.) and Swiss chard (Beta Vulgaris L. Var. cycla). Agric Ecosyst Environ. 2016;235:215-28.

17. Yoon HS, Lee H, Lee IA, Kim KY, Jo J. Molecular cloning of the monodehydroascorbate reductase gene from Brassica campestris and analysis of its mRNA level in response to oxidative stress. Biochim Biophys Acta. 2004;1658:181-6.

18. Keck AS, Finley JW. Cruciferous vegetables: cancer protective mechanisms of glucosinolate hydrolysis products and selenium. Integr Cancer Ther. 2004; 3:5-12.

19. Zhang L, Xiao S, Chen YJ, Xu H, Li YG, Zhang YW, Luan FS. Ozone sensitivity of four Pakchoi cultivars with different leaf colors: physiological and biochemical mechanisms. Photosynthetica. 2017;55:478-90.

20. Olbrich M, Betz G, Gerstner E, Langebartels C, Sandermann H, Ernst D. Transcriptome analysis of ozone-responsive genes in leaves of European beech (Fagus sylvatica L.). Plant Biol. 2005;7:670-6. 
21. Mahalingam R, Shah N, Scrymgeour A, Fedoroff N. Temporal evolution of the Arabidopsis oxidative stress response. Plant Mol Biol. 2005;57:709-30.

22. Vingarzan R. A review of surface ozone background levels and trends. Atmos Environ. 2004;38:3431-42.

23. Liu F, Zhu Y, Wang X. Surface ozone pollution and its eco-environmental impacts in China ecol. Environment. 2008;17:1674-9. (in Chinese with English abstract)

24. Sharma YK, León J, Raskin I, Davis KR. Ozone-induced responses in Arabidopsis thaliana: the role of salicylic acid in the accumulation of defense-related transcripts and induced resistance. Proc Natl Acad Sci U S A. 1996;93:5099-104.

25. Ernst D, Schraudner M, Langebartels C, JrH S. Ozone-induced changes of mRNA levels of $\beta-1,3-g l u c a n a s e$, chitinase and 'pathogenesis-related' protein 1b in tobacco plants. Plant Mol Biol. 1992;20:673-82.

26. Yalpani N, Enyedi AJ, León J, Raskin I. Ultraviolet light and ozone stimulate accumulation of salicylic acid, pathogenesis-related proteins and virus resistance in tobacco. Planta. 1994;193:372-6.

27. Eckey-Kaltenbach H, Kiefer E, Grosskopf E, Ernst D, JrH S. Differential transcript induction of parsley pathogenesis-related proteins and of a small heat shock protein by ozone and heat shock. Plant Mol Biol. 1997;33:343-50.

28. Gunthardt-Goerg MS, Matyssek R, Scheidegger C, Keller T. Differentiation and structural decline in the leaves and bark of birch (Betula pendula) under low ozone concentrations. Trees. 1993;7:104-14.

29. Paakkonen E, Metsarinne S, Holopainen T, Karenlampi L. The ozone sensitivity of birch (Betula pendula Roth.) in relation to the developmental stage of leaves. New Phytol. 1995;132:145-54.

30. Frey B, Scheidegger C, Gunthardt-Goerg MS, Matyssek R. The effects of ozone and nutrient supply on stomatal response in birch (Betula pendula) leaves as determined by digital image-analysis and x-ray microanalysis. New Phytol. 1996;32:221-35

31. Kontunen-Soppela S, Riikonen J, Ruhanen H, Brosche M, Somervuo P, Peltonen P, Kangasjarvi J, Auvinen P, Paulin L, Keinanen M, Oksanen E, Vapaavuori E. Differential gene expression in senescing leaves of two silver birch genotypes in response to elevated $\mathrm{CO}_{2}$ and tropospheric ozone. Plant Cell Environ. 2010;33:1016-28.

32. Rao MV, Paliyath G, Ormrod DP. Ultraviolet-B-and ozone-induced biochemical changes in antioxidant enzymes of Arabidopsis thaliana. Plant Physiol. 1996;110:125-36.

33. Sharma YK, Davis KR. The effects of ozone on antioxidant responses in plants. Free Radic Biol Med. 1997;23:480-8.

34. Agrawal GK, Rakwal R, Iwahashi H. Isolation of novel rice (Oryza Sativa L) multiple stress responsive MAP kinase gene, OsMSRMK2, whose mRNA accumulates rapidly in response to environmental cues. Biochem Biophys Res Commun. 2002;294:1009-16.

35. Paoletti E, Castagna A, Ederli L, Pasqualini S, Ranieri A, Manning WJ. Gene expression in snap beans exposed to ozone and protected by ethylenediurea. Environ Pollut. 2014;193:1-5.

36. Bohler S, Bagard M, Oufir M, Planchon S, Hoffmann L, Jolivet $Y$, Hausman JF, Dizengremel P, Renaut J. A DIGE analysis of developing poplar leaves subjected to ozone reveals major changes in carbon metabolism. Proteomics. 2007;7:1584-99.

37. Agrawal GK, Jwa NS, Rakwal R. A pathogen-induced novel rice (Oryza sativa L.) gene encodes a putative protein homologous to type II glutathione Stransferases. Plant Sci. 2002;163:1153-60.

38. Mueller LA, Goodman CD, Silady RA, Walbot V. AN9, a petunia glutathione S-transferase required for anthocyanin sequestration, is a flavonoid-binding protein. Plant Physiol. 2000;123:1561-70.

39. Kampranis SC, Damianova R, Atallah M, Toby G, Kondi G, Tsichlis PN, Makris AM. A novel plant glutathione S-transferase/peroxidase suppresses Bax lethality in yeast. J Biol Chem. 2000;275:29207-16.

40. Vijayakumar H, Thamilarasan SK, Shanmugam A, Natarajan S, Jung HJ, Park II, Kim HR, Chung MY, Nou IS. Glutathione transferases superfamily: coldinducible expression of distinct GST genes in Brassica oleracea. Int J Mol Sci. 2016;17:1211.

41. Narusaka M, Seki M, Umezawa T, Ishida J, Nakajima M, Enju A, Shinozaki K. Crosstalk in the responses to abiotic and biotic stresses in Arabidopsis: analysis of gene expression in cytochrome P450 gene superfamily by CDNA microarray. Plant Mol Biol. 2004;55:327-42.

42. Mueller S, Hilbert B, Dueckershoff K, Roitsch T, Krischke M, Mueller MJ, Berger S. General detoxification and stress responses are mediated by oxidized lipids through TGA transcription factors in Arabidopsis. Plant Cell. 2008;20:768-85
43. Sandermann H. Plant metabolism of xenobiotics. Trends Biochem Sci. 1992; $17: 82-4$.

44. Mène-Saffrané L, Dubugnon L, Chételat A, Stolz S, Gouhier-Darimont C, Farmer EE. Nonenzymatic oxidation of trienoic fatty acids contributes to reactive oxygen species management in Arabidopsis. J Biol Chem. 2009;284: 1702-8.

45. Rao MV, Koch JR, Davis KR. Ozone: a tool for probing programmed cell death in plants. Plant Mol Biol. 2000;44:345-58.

46. Tuominen $H$, Overmyer $K$, Keinänen $M$, Kollist $H$, Kangasjärvi J. Mutual antagonism of ethylene and jasmonic acid regulates ozone-induced spreading cell death in Arabidopsis. Plant J. 2004;39:59-69.

47. Yu J, Zhang Y, Di C, Zhang Q, Zhang K, Wang C, You Q, Yan H, Dai SY, Yuan JS, Xu W, Su Z. JAZ7 negatively regulates dark-induced leaf senescence in Arabidopsis. J Exp Bot. 2016;67:751-62.

48. Thines B, Katsir L, Melotto M, Niu Y, Mandaokar A, Liu G, Nomura K, He SY, Howe GA, Browse J. JAZ repressor proteins are targets of the SCF ${ }^{\text {COI1 }}$ complex during jasmonate signalling. Nature. 2007;448:661-6.

49. Grunewald W, Vanholme B, Pauwels L, Plovie E, Inzé D, Gheysen G, Goossens A. Expression of the Arabidopsis jasmonate signalling repressor JAZ1/TIFY10A is stimulated by auxin. EMBO Rep. 2009;10:923-8.

50. Kulik A, Wawer I, Krzywińska E, Bucholc M, Dobrowolska G. SnRK2 protein kinases-key regulators of plant response to abiotic stresses. Omics: J Integr Biol. 2011;15:859-72.

51. Xu ZS, Chen M, Li LC, Ma YZ. Functions and application of the AP2/ERF transcription factor family in crop improvement. J Integr Plant Biol. 2011;53: 570-85

52. Mizoi J, Shinozaki K, Yamaguchi-Shinozakia K. AP2/ERF family transcription factors in plant abiotic stress responses. Biochim Biophys Acta. 1819;2012: 86-96.

53. Khandelwal A, Elvitigala T, Ghosh B, Quatrano RS. Arabidopsis transcriptome reveals control circuits regulating redox homeostasis and the role of an AP2 transcription factor. Plant Physiol. 2008;148:2050-8.

54. Ludwików A, Kierzek D, Gallois P, Zeef L, Sadowski J. Gene expression profiling of ozone-treated Arabidopsis abiltd insertional mutant: protein phosphatase 2C ABI1 modulates biosynthesis ratio of $\mathrm{ABA}$ and ethylene. Planta. 2009;230:1003-17.

55. Pan Y, Seymour GB, Lu C, Hu Z, Chen X, Chen G. An ethylene response factor (ERF5) promoting adaptation to drought and salt tolerance in tomato. Plant Cell Rep. 2012;31:349-60.

56. Haake V, Cook D, Riechmann J, Pineda O, Thomashow MF, Zhang JZ. Transcription factor CBF4 is a regulator of drought adaptation in Arabidopsis. Plant Physiol. 2002;130:639-48.

57. Luo J, Tang S, Mei F, Peng X, Li J, Li X, Yan X, Zeng X, Liu F, Wu Y, Wu G. BnSIP1-1, a trihelix family gene, mediates abiotic stress tolerance and ABA signaling in Brassica napus. Front Plant Sci. 2017:8:44.

58. Lee SC, Lim MH, Kim JA, Lee SI, Kim JS, Jin M, Kwon SJ, Mun JH, Kim HU, Hur Y, Park BS. Transcriptome analysis in Brassica rapa under the abiotic stresses using Brassica 24K oligo microarray. Mol Cells. 2008;26: 595-605.

59. Ayadi M, Delaporte V, Li YF, Zhou DX. Analysis of GT-3a identifies a distinct subgroup of trihelix DNA-binding transcription factors in Arabidopsis. FEBS Lett. 2004;562:147-54.

60. Park HC, Kim ML, Kang YH, Jeon JM, Yoo JH, Kim MC, Park CY, Jeong JC, Moon BC, Lee JH, Yoon HW, Lee SH, Chung WS, Lim CO, Lee SY, Hong JC, Cho MJ. Pathogen-and $\mathrm{NaCl}$-induced expression of the SCaM4 promoter is mediated in part by a GT-1 box that interacts with a GT1-like transcription factor. Plant Physiol. 2004;135:2150-61.

61. Cho K, Shibato J, Agrawal GK, Jung YH, Kubo A, Jwa NS, Tamogami S, Satoh K, Higashi T, Kimura S, Saji H, Tanaka Y, Iwahashi H, Masuo Y, Rakwal R. Integrated transcriptomics, proteomics, and metabolomics analyses to survey ozone responses in the leaves of rice seedling. J Proteome Res. 2008;7:2980-98.

62. Tosti N, Pasqualini S, Borgogni A, Ederli L, Falistocco E, Crispi S, Paolocci F. Gene expression profiles of $\mathrm{O}_{3}$-treated Arabidopsis plants. Plant Cell Environ. 2006;29:1686-702.

63. Gao QM, Venugopal S, Navarre D, Kachroo A. Low oleic acid-derived repression of jasmonic acid-inducible defense responses requires the WRKY50 and WRKY51 proteins. Plant Physiol. 2011;155:464-76.

64. Iyer NJ, Tang Y, Mahalingham R. Physiological, biochemical and molecular responses to a combination of drought and ozone in Medicago truncatula. Plant Cell Environ. 2013;36:706-20. 
65. Robatzek S, Somssich IE. A new member of the Arabidopsis WRKY transcription factor family, AtWRKY6, is associated with both senescenceand defence-related processes. Plant J. 2001;28:123-33.

66. Tang J, Wang F, Wang Z, Huang Z, Xiong A, Hou X. Characterization and co-expression analysis of WRKY orthologs involved in responses to multiple abiotic stresses in Pak-choi (Brassica campestris Ssp. chinensis). BMC Plant Biol. 2013;13:188.

67. Rizzo M, Bernardi R, Salvini M, Nali C, Lorenzini G, Durante M. Identification of differentially expressed genes induced by ozone stress is sensitive and tolerant poplar hybrids. J Plant Physiol. 2007;164:945-9.

68. Xie XB, Li S, Zhang RF, Zhao J, Chen YC, Zhao Q, Yao YX, You CX, Zhang XS, Hao YJ. The bHLH transcription factor MdbHLH3 promotes anthocyanin accumulation and fruit colouration in response to low temperature in apples. Plant Cell Environ. 2012;35:1884-97.

69. Kimura T, Shibagaki N, Ohkama-Ohtsu N, Hayashi H, Yoneyama T, Davies JP, Fujiwara T. Arabidopsis SNRK2.3 protein kinase is involved in the regulation of sulfur-responsive gene expression and O-acetyl-L-serine accumulation under limited sulfur supply. Soil Sci. Plant Nutr. 2006;52:211-20.

70. Debeaujon I, Peeters AJM, Léon-Kloosterziel KM, Koornneef M. The TRANSPARENT TESTA 12 gene of Arabidopsis encodes a multidrug secondary transporter-like protein required for flavonoid sequestration in vacuoles of the seed coat endothelium. Plant Cell. 2001:13:853-71.

71. Chai YR, Lei B, Huang HL, Li JN, Yin JM, Tang ZL, Wang R, Chen L. TRANSPARENTTESTA12 genes from Brassica napus and parental species: cloning, evolution, and differential involvement in yellow seed trait. Mol Gen Genomics. 2009;281:109-23.

72. Elortza F, Nuhse TS, Foster L, Stensballe A, Peck SC, Jensen ON. Proteomic analysis of glycosylphosphatidylinositol-anchored membrane proteins. Mol Cell Proteomics. 2003;2:1261-70.

73. Simpson C, Thomas C, Findlay K, Bayer E, Maule AJ. An Arabidopsis GPIanchor plasmodesmal neck protein with callose binding activity and potential to regulate cell-to-cell trafficking. Plant Cell. 2009;21:581-94.

74. Yuan X, Calatayud V, Gao F, Fares S, Paoletti E, Tian Y, Feng Z. Interaction of drought and ozone exposure on isoprene emission from extensively cultivated poplar. Plant Cell Environ. 2016:39:2276-87.

75. Hu EZ, Gao F, Xin Y, Jia HX, Li KH, Hu JJ, Feng Z. Concentration- and fluxbased ozone dose-response relationships for five poplar clones grown in North China. Environ Pollut. 2015;207:21-30.

76. CLRTAP. Mapping Critical Levels for Vegetation, Chapter III of Manual on methodologies and criteria for modelling and mapping critical loads and levels and air pollution effects, risks and trends. UNECE Convention on Long-range Transboundary Air Pollution. 2015. http://www.icpmapping.org. Accessed 14 Apr 2016

77. Cheng F, Liu S, Wu J, Fang L, Sun S, Liu B, Li P, Hua W, Wang X. BRAD, the genetics and genomics database for Brassica plants. BMC Plant Biol. 2011;11:1-6.

78. Wang L, Feng Z, Wang X, Wang X, Zhang X. DEGseq: an R package for identifying differentially expressed genes from RNA-Seq data. Bioinformatics. 2010;26:136-8

79. Young MD, Wakefield MJ, Smyth GK, Oshlack A. Gene ontology analysis for RNA-seq: accounting for selection bias. Genome Biol. 2010;11:R14.

80. Mao X, Cai T, Olyarchuk JG, Wei L. Automated genome annotation and pathway identification using the KEGG Orthology (KO) as a controlled vocabulary. Bioinformatics. 2005;21:3787-93.

81. Chandna R, Augustine R, Bisht NC. Evaluation of candidate reference genes for gene expression normalization in Brassica juncea using real time quantitative RT-PCR. PLoS One. 2012;7(5):e36918.

82. Livak KJ, Schmittgen TD. Analysis of relative gene expression data using real-time quantitative $P C R$ and the $2^{-\Delta \Lambda C T}$ method. Methods. 2001:25:402-8.

\section{Submit your next manuscript to BioMed Central and we will help you at every step:}

- We accept pre-submission inquiries

- Our selector tool helps you to find the most relevant journal

- We provide round the clock customer support

- Convenient online submission

- Thorough peer review

- Inclusion in PubMed and all major indexing services

- Maximum visibility for your research

Submit your manuscript at www.biomedcentral.com/submit
C Biomed Central 